\title{
Surface epithelium related activation of complement differs in Crohn's disease and ulcerative colitis
}

\author{
T S Halstensen, T E Mollnes, P Garred, O Fausa, P Brandtzaeg
}

\begin{abstract}
IgG1 and activated complement are colocalised on the colonic epithelial brush border in active ulcerative colitis. To investigate whether such deposition is specific for ulcerative colitis, we examined ethanol fixed mucosal specimens from 18 patients with Crohn's colitis and 14 with terminal ileitis by indirect two colour immunofluorescence staining. Monoclonal antibodies to the IgG subclasses and to neoepitopes of activated complement $\mathrm{C} 3 \mathrm{~b}$ and the terminal complement complex were used in combination with rabbit antiserum to C1q, C4c or cytokeratin. Granular deposition of C3b and terminal complement complex were observed at the luminal face of the surface epithelium in 10 of 18 patients with Crohn's colitis. Specimens from eight of 14 patients with ileal involvement were intensely stained for activated complement (primarily C3b) within the surface mucus layer. No epithelial IgG, Clq or $\mathrm{C} 4 \mathrm{c}$ deposition was observed. The results suggest that early and late phase complement activation takes place at the luminal face of the epithelium in Crohn's disease. The absence of colocalised IgG and complement components involved in the classical activation pathway (Clq and $\mathrm{C} 4 \mathrm{c}$ ), however, suggest that other immunopathological mechanisms (the alternative pathway?) are primarily involved in Crohn's disease in contrast with ulcerative colitis.
\end{abstract}

Laboratory for

Immunohistochemistry and Immunopathology (LIIPAT), Institute of Pathology

T S Halstensen

P Brandtzaeg

Institute of Immunology and Rheumatology T E Mollnes P Garred

Section of Gastroenterology O Fausa

Medical Department A, University of Oslo, The National Hospital, Rikshospitalet, Oslo, Norway

Correspondence to: Dr Trond S Halstensen, LIIPAT, Rikshospitalet, N-0027 Oslo 1, Norway.

Accepted for publication 7 October 1991
Crohn's disease is a chronic inflammatory bowel disease of unknown aetiology and pathogenesis. ' Immunohistochemical studies have revealed a strikingly increased local immunoglobulin G (IgG) production, ${ }^{2}$ predominantly of the complement binding IgGl subclass although Crohn's disease mucosa contains a higher percentage of IgG2 containing immunocytes than ulcerative colitis. ${ }^{3}$ The same result has been obtained by cultivation of mononuclear cells from the lesion. ${ }^{+}$ Patients with Crohn's disease are reported to have impaired $\mathrm{C} 3 \mathrm{~b}$ inactivation ${ }^{5}$ and increased complement C3 catabolism $^{6-8}$ with raised serum concentrations of complement $\mathrm{C} 3$ activation split products. ${ }^{910}$ These findings suggest that complement activation takes place in the affected intestinal mucosa.

To address this issue we examined directly ethanol fixed as well as extensively pre-washed mucosal specimens from patients with Crohn's disease in the ileum and/or colon. Monoclonal antibody $(\mathrm{mAb})$ to activation neoepitopes in the early (C3b) and late (terminal complement complex complement activation pathway were used.
The results showed deposition of both $\mathrm{C} 3 \mathrm{~b}$ and terminal complement complex in these deposits, however, in contrast with our previous observations in ulcerative colitis. ${ }^{11}$

\section{Methods}

TISSUE SPECIMENS

Mucosal tissue samples were immediately excised from surgically resected colon $(n=56)$ or terminal ileum $(n=26)$ from 21 patients with Crohn's disease (median age $29 \mathrm{yr}$, range 14-64). Three patients had only ileal involvement, one only colonic, whereas 17 had both segments affected (ileal biopsy available only in 11). The patients had been observed clinically for two to 13 years (median five years). Ulcerative colitis specimens (five) with epithelial complement and IgG1 deposits were selected from 23 previously reported patients. " Control material was obtained from histologically normal colonic mucosa of 26 patients as described elsewhere ${ }^{11}$ and normal ileal mucosa (six).

All tissue specimens were placed in ice cold isotonic saline and brought to the laboratory within one hour for preparation in two alternative ways. Trimmed tissue blocks (about $2 \times 4 \times 5 \mathrm{~mm}$ ) were either fixed directly in cold $96 \%$ ethanol for 18 hours to preserve soluble immune complexes (17 ileal and 33 colonic samples), or washed for 48 hours at $4^{\circ} \mathrm{C}$ in 0.01 $\mathrm{M}$ phosphate buffer ( $\mathrm{pH} 7.5$ ) containing $0.15 \mathrm{M}$ $\mathrm{NaCl}$ (phosphate buffered saline to extract diffusible proteins before cold ethanol fixation (nine ileal and 23 colonic samples). All tissue samples were finally dehydrated in cold absolute ethanol, cleared in xylene, embedded in paraffin for three to four hours at $56^{\circ} \mathrm{C}$, and stored at $4^{\circ} \mathrm{C}$ until sectioning. ${ }^{12}$

\section{STAINING PROCEDURES AND IMMUNOLOGICAL} REAGENTS

Dewaxed sections cut at $6 \mu \mathrm{m}$ from directly fixed tissue were incubated for 20 hours at room temperature with monoclonal antibody to a C9 neoepitope of terminal complement complex $(\mathrm{aE} 11 ; 2.5 \mathrm{mg} / \mathrm{l})^{13}$ in combination with rabbit antiserum to S-protein/vitronectin (1:5000; kindly provided by B Dahlbäck, Department of Clinical Chemistry, Malmö General Hospital, Sweden). ${ }^{14}$ An alternative combination was monoclonal antibody to a $\mathrm{C} 3 \mathrm{~b}$ neoepitope in the $\mathrm{C} 3 \mathrm{c}$ part of $\mathrm{C} 3 \mathrm{~b} / \mathrm{iC} 3 \mathrm{~b}(\mathrm{bH} 6,7 \cdot 5 \mathrm{mg} / \mathrm{l})^{15}$ and rabbit antiserum to cytokeratin $(1: 100) .^{16}$

Dewaxed sections of prewashed tissue were examined both for IgG deposits and complement activation products. Monoclonal antibodies to 
C3b, TCC, IgG1 (clone 267, 1:800; HP 6070), ${ }^{17}$ IgG2 (clone GOM2, 1:800; HP6009), ${ }^{17} \mathrm{OgG} 3$ (clone CBI-AH7, 1:800; HP6048) ${ }^{17}$ and IgG4 (clone RJ4, 1:8000; HP6011) ${ }^{17}$ were all used in combination with rabbit antiserum to $\mathrm{C} 3 \mathrm{c}$ (1:500; Behring, Marburg, Germany) as previously described. ${ }^{11}$

Selected colonic (three) and ileal (two) specimens from five patients with Crohn's disease and five with ulcerative colitis found to have apical complement deposition (see below) were, in addition, examined with rabbit antiserum to $\mathrm{Clq}$ (1:500; Dakopatts, Glostrup, Denmark); C3c (1:500; Behring) and C4c (1:500, Dakopatts) in combination with monoclonal antibody to $\mathrm{C} 3 \mathrm{~b}$ or terminal complement complex. Secondary reagents were biotinylated horse antimouse IgG (0.025 g/l; Vector Laboratories, Burlingame, CA, USA), followed either by swine antirabbit IgG $(0 \cdot 14 \mathrm{~g} \mathrm{IgG/l}$; Dakopatts) conjugated with rhodamine ${ }^{18}$ in combination with fluorescein Isothiocyanate (FITC) conjugated streptavidin ( $0.02 \mathrm{~g} / \mathrm{l}$; Boehringer Manheim, Germany), or by fluorescein isothiocyanate conjugated swine antirabbit IgG (1:10, Dakopatts) combined with Streptavidin-Texas Red (0.0025 g/l; BRL, Gaithersburg, MD, USA). The reagents were applied in a three step two colour immunofluorescence staining method principally as described elsewhere. ${ }^{18}$ The selected prewashed specimens were also subjected to three colour staining in which monoclonal antibody to human IgG1 (murine IgG1) was combined with monoclonal antibody bH6 to C3b (IgG2a) or monoclonal antibody aE11 to terminal complement complex (IgG2a), and mixed with rabbit antiserum to $\mathrm{C} 3 \mathrm{c}$ or $\mathrm{C} 4 \mathrm{c}$. Secondary reagents were biotinylated and fluorescein Isothiocyanate conjugated subclass specific goat antimouse IgG2a and IgG1 (Southern Biotechnology, Birmingham, AL, USA) followed by 7-amino-4-methylcoumarin-3acetic acid (conjugated goat antirabbit $\operatorname{IgG}(1: 20$, Vector Laboratories) in combination with Streptavidin-Texas Red (0.0025 g/l; BRL).

Selected colonic specimens (six) with $\mathrm{C} 3 \mathrm{~b}$ positive globular elements in the lamina propria (see later) were also examined for terminal complement complex and $\mathrm{C} 3 \mathrm{~b}$ deposition by immunoenzyme staining; the alkaline phospha-

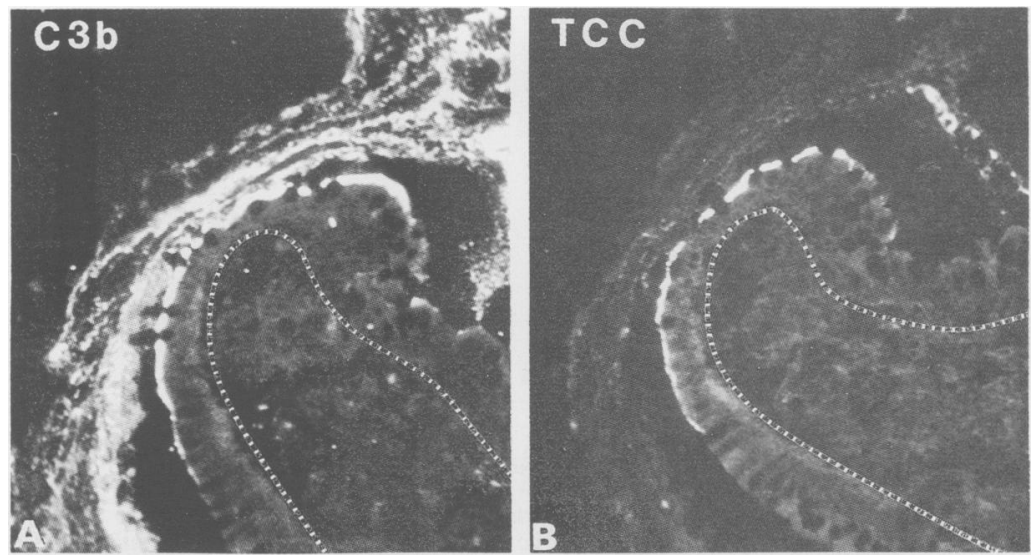

Figure 1: Intense $C 3 b$ positivity (a) was noted in the mucus layer and apically on the epithelium, whereas terminal complement complex $(T C C)(b)$ was selectively deposited on the epithelial surface. Broken line indicates the basement membrane zone. Paired immunofluorescence staining in section of directly ethanol fixed ileal mucosa from a patient with Crohn's disease of the ileum. tase antialkaline phosphatase ${ }^{19}$ and the avidinbiotin complex peroxidase methods were both applied, the latter according to the instructions given by the manufacturer (Dakopatts).

\section{IMMUNOHISTOCHEMICAL}

EVALUATION,

CONTROLS,

AND STATISTICAL ANALYSIS

Immunofluorescence was examined in a Leitz Orthoplan microscope equipped with a Ploem type vertical illuminator for selective observation of red (rhodamine), green fluorescein Isothiocyanate or blue 7-amino-4-methylcoumarin-3acetic acid emmission. For every immunofluorescence marker, each specimen was given a semiquantitative score ranging from no $(-)$ to intense $(3+)$ staining. Scoring of the unselected Crohn sections was done blind by the same investigator. Mucus associated and the strictly epithelium related complement deposits were scored separately. One section from every series was subjected to blind histopathological evaluation after haematoxylin and eosin staining; each specimen thereby received an arbitrary inflammation score from negative $(-)$ to intense $(3+)$ according to cellular infiltration and mucosal destruction.

Primary incubation with murine control ascites or normal rabbit serum, at dilutions similar to those used for monoclonal antibodies and rabbit antisera, did not produce immunofluorescence.

The relation between mucus associated and/or epithelium related terminal complement complex/C3b deposits and inflammation was based on Kendall's correlation analysis.

\section{Results}

\section{ILEAL COMPLEMENT DEPOSITS}

Staining for C3b-neo (monoclonal antibody bH6) was observed within the ileal surface mucus layer in directly fixed specimens from eight of 14 patients. Additional but weaker and scattered staining for terminal complement complex was observed in five of these patients. A distinct epithelium related apical staining for $\mathrm{C} 3 \mathrm{~b}$ was observed in seven patients, and four of them showed terminal complement complex at the same location (Table) C3b often dominated throughout the mucus layer whereas terminal complement complex appeared to be located closer to the epithelial surface and was then scored as epithelium related (Fig 1). Only the staining intensity of epithelium related and mucus associated terminal complement complex was significantly correlated with the topical degree of inflammation (Fig 2), although wide scatter was observed. Fine granular staining for terminal complement complex and S-protein was present in the basement membrane zone of five patients, whereas $\mathrm{C} 3 \mathrm{~b}$ was seen in only one. No epithelial deposition of $\mathrm{Clq}, \mathrm{C} 4 \mathrm{c}$ or any of the four IgG subclasses was detected in the prewashed specimens.

An approximately $100 \mu \mathrm{m}$ broad zone of the mucosal wall surrounding ileal ulcers stained 
Clinicopathological information about the patients with Crohn's disease of the colon and scoring of inflammation and epithelium related immune deposits

\begin{tabular}{|c|c|c|c|c|c|c|c|c|c|c|c|c|}
\hline \multirow[b]{2}{*}{$\begin{array}{l}\text { Patient } \\
\text { no }\end{array}$} & \multirow{2}{*}{$\begin{array}{l}\text { Sex/age } \\
(y r)\end{array}$} & \multirow{2}{*}{$\begin{array}{l}\text { Disease } \\
\text { duration } \\
(y r)\end{array}$} & \multicolumn{2}{|c|}{ Medicationt } & \multirow[b]{2}{*}{$\begin{array}{l}\text { Clinical } \\
\text { activity }\end{array}$} & \multirow[b]{2}{*}{ Location $\neq$} & \multirow{2}{*}{$\begin{array}{l}\text { Inflam- } \\
\text { mation }\end{array}$} & \multicolumn{2}{|c|}{ Mucus } & \multicolumn{2}{|c|}{ Epithelium } & \multirow{2}{*}{$\begin{array}{l}B M Z \\
T C C\end{array}$} \\
\hline & & & $S$ & $P$ & & & & $C 3 b$ & $T C C$ & $C 3 b$ & $T C C$ & \\
\hline 1 & $M / 47$ & 4 & No & No & Mild & Ileum & $2+$ & $3+$ & $3+$ & $3+$ & $2+$ & - \\
\hline 2 & M/26 & 3 & No & No & Mild & Ileum & $2+$ & $3+$ & $1+$ & $1+$ & - & - \\
\hline 3 & $\mathrm{M} / 47$ & 4 & No & Yes & Moderate & Ileum & $3+$ & - & - & - & - & $3+$ \\
\hline \multirow[t]{2}{*}{4} & M/40 & 4 & No & No & Mild & Ileum & $1+$ & - & - & - & - & $3+$ \\
\hline & & & & & & Coecum & $2+$ & $3+$ & $2+$ & - & - & $3+$ \\
\hline 5 & M/15 & 3 & No & No & Mild & Ileum & $2+$ & $2+$ & $2+$ & - & $1+$ & - \\
\hline \multirow[t]{2}{*}{6} & $F / 25$ & 4 & No & Yes & Moderate & $\begin{array}{l}\text { Colon S } \\
\text { Ileum }\end{array}$ & $\begin{array}{l}3+ \\
2+\end{array}$ & - & - & $\overrightarrow{2}+$ & $\overline{2}+$ & $1+$ \\
\hline & & & & 100 & Druterate & Colon T & $1+$ & $3+$ & $3+$ & - & - & $1+$ \\
\hline \multirow[t]{2}{*}{7} & M/18 & 13 & Yes & No & Moderate & Ileum & $1+$ & $1+$ & - & $1+$ & - & - \\
\hline & & & & & & Colon A & $3+$ & $1+$ & - & $1+$ & $1+$ & - \\
\hline \multirow[t]{2}{*}{8} & $F / 35$ & 5 & No & No & Moderate & Ileum & $2+$ & $3+$ & $2+$ & - & - & - \\
\hline & & & & & & Colon $S$ & $1+$ & - & - & - & - & - \\
\hline \multirow[t]{2}{*}{9} & $F / 17$ & 2 & No & Yes & Mild & Ileum & - & - & - & - & - & - \\
\hline & & & & & & Colon T & $2+$ & $1+$ & $1+$ & $2+$ & $2+$ & - \\
\hline \multirow[t]{2}{*}{10} & M/29 & 10 & No & No & Moderate & Ileum & $2+$ & $1+$ & $3+$ & - & - & - \\
\hline & & & & & & Colon D & $1+$ & $2+$ & $3+$ & - & - & - \\
\hline 11 & $F / 23$ & 2 & No & Yes & Mild & Ileum & $2+$ & $1+$ & $1+$ & $1+$ & $1+$ & $\overline{1}$ \\
\hline \multirow[t]{2}{*}{12} & $\mathrm{M} / 30$ & 7 & Yes & No & Moderate & $\begin{array}{l}\text { Loecum } \\
\text { Ileum }\end{array}$ & $\begin{array}{l}3+ \\
3+\end{array}$ & $\begin{array}{l}2+ \\
1+\end{array}$ & $\frac{1+}{-}$ & $\begin{array}{l}1+ \\
1+\end{array}$ & $\overline{2}+$ & $\begin{array}{l}1+ \\
1+\end{array}$ \\
\hline & & & & & & Colon A & $1+$ & - & $1+$ & $1+$ & $2+$ & $1+$ \\
\hline \multirow[t]{2}{*}{13} & M/64 & 10 & Yes & Yes & Moderate & Ileum & $3+$ & - & $3+$ & - & - & $2+$ \\
\hline & & & & & & Colon A & - & - & - & - & - & - \\
\hline \multirow[t]{2}{*}{14} & $F / 14$ & 6 & No & Yes & Mild & Ileum & $1+$ & - & - & - & - & $1+$ \\
\hline & & & & & & Colon A & $\overline{2}$ & - & $\overline{1}$ & - & - & $1+$ \\
\hline $\begin{array}{l}15 \\
16\end{array}$ & $\begin{array}{l}F / 21 \\
F / 24\end{array}$ & $\begin{array}{l}5 \\
8\end{array}$ & $\begin{array}{l}\text { Yes } \\
\text { Yes }\end{array}$ & $\begin{array}{l}\text { Yes } \\
\text { Yes }\end{array}$ & $\begin{array}{l}\text { Severe } \\
\text { Severe }\end{array}$ & $\begin{array}{l}\text { Colon D } \\
\text { Colon A }\end{array}$ & $\begin{array}{l}2+ \\
2+\end{array}$ & $\overline{1}+$ & $1+$ & $\overline{1}+$ & - & $\overline{1}$ \\
\hline $\begin{array}{l}16 \\
17\end{array}$ & $\begin{array}{l}\text { F/24 } \\
M / 38\end{array}$ & $\begin{array}{l}0 \\
9\end{array}$ & $\begin{array}{l}\text { Yes } \\
\text { No }\end{array}$ & $\begin{array}{l}\text { Yes } \\
\text { No }\end{array}$ & $\begin{array}{l}\text { Severe } \\
\text { Mild }\end{array}$ & $\begin{array}{l}\text { Colon A } \\
\text { Colon A }\end{array}$ & - & ${ }_{-}^{1+}$ & - & $1+$ & $2+$ & $1+$ \\
\hline 18 & $M / 19$ & 4 & Yes & Yes\| & Severe & Rectum & $3+$ & - & - & $\overline{1}+$ & $\overline{2}+$ & $\begin{array}{l}- \\
-\end{array}$ \\
\hline 19 & $\mathrm{~F} / 30$ & 4 & Yes & Yes & Moderate & Rectum & $2+$ & $3+$ & $1+$ & - & $1+$ & $2+$ \\
\hline 20 & M/36 & 9 & No & Yes & Mild & Colon S & $3+$ & $2+$ & $3+$ & $1+$ & $3+$ & $2+$ \\
\hline 21 & $F / 64$ & 13 & No & No & Mild & Colon S & $3+$ & - & - & $1+$ & - & - \\
\hline
\end{tabular}

* $M=$ male,$F=$ female,$+S=$ salazopyrin, $P=$ prednisone, $\neq$ colon $S=$ sigmoid colon, colon $A=$ ascending colon, colon $T=$ transverse colon, $\S \mathrm{BMZ}=$ basement membrane zone, $\|$ patient received Imurel (azathioprin).

diffusely for terminal complement complex, and numerous terminal complement complex positive globular elements were observed in the luminal content (not shown).

\section{COLONIC COMPLEMENTS DEPOSITS}

\section{Crohn's disease}

Often granular and parallel positivity for $\mathrm{C} 3 \mathrm{~b}$ (Fig 3) and terminal complement complex was observed at the luminal face of the epithelium in 10 of 18 patients with Crohn's disease of the colon (Table). The staining intensity for strictly epithelium-related (Fig 2b) C3b and terminal complement complex was better correlated with the topical degree of inflammation (Fig 2a) than the mucus associated. Granular terminal complement complex positivity in the basement membrane zone was often observed beneath intact epithelium in nine of the patients. The content in colonic fissures was, like that in crypt abscesses, often intensely positive for terminal complement complex but mostly negative for C3b. Globular elements with various combination of peripheral positivity for IgG subclasses (IgG2>IgG3 >IgG1) and/or C3b were observed within the mucus associated content, whereas

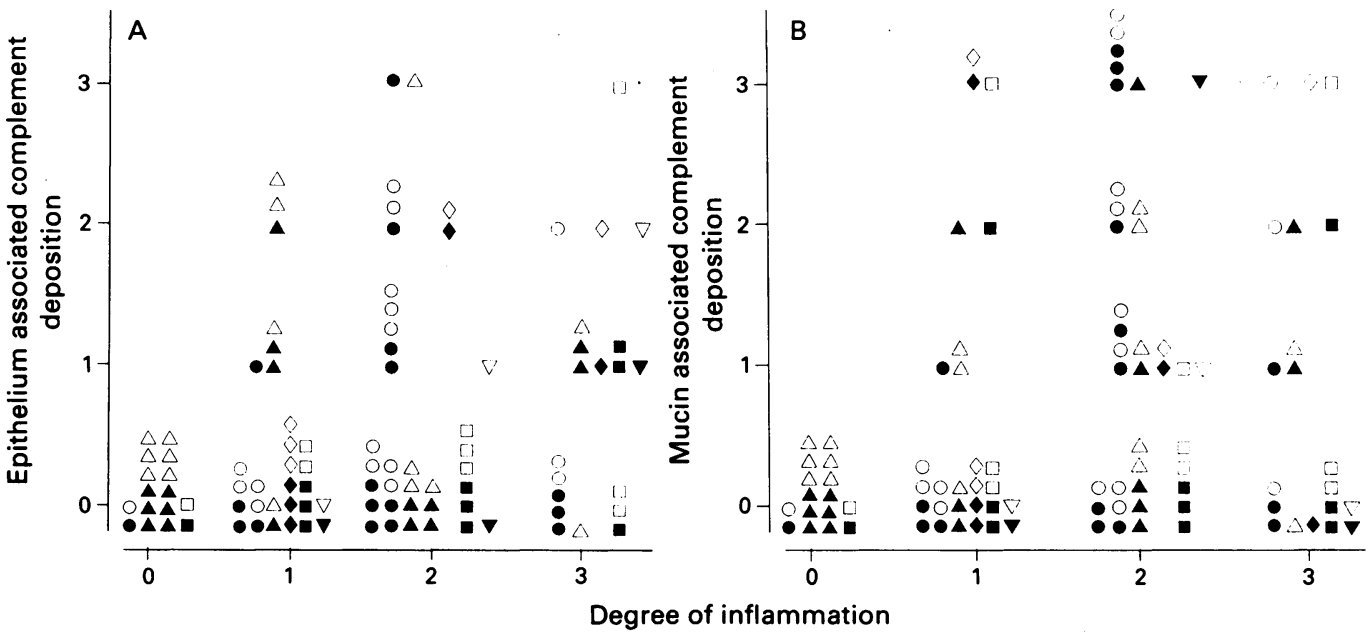

Figure 2: Scatter diagram showing intensity of $(a)$ epithelium related and $(b)$ mucus associated complement related to the degree of inflammation in Crohn patients (controls not shown). Epithelium related and mucus associated terminal complement complex (but not $C 3 b$ ) correlated with the topical degree of ileal inflammation $(\tau=0.33$ and $\tau=0.41$, respectively; $p<0.01)$, whereas both the epithelium-related $C 3 b(\tau=0.45)$ and terminal complement complex $(\tau=0.38)$ correlated with the degree of inflammation in the large bowel $(p<0.0001)$. The mucus associated terminal complement complex (but not C $3 b$ ) showed a weak correlation with the topical degree of colonic inflammation $(\tau=0 \cdot 27 ; p<0.005)$. Filled symbols represent $C 3 b$, open weak correlation with the topical degree of colonic inflammation $(\tau=0 \cdot 27 ; p<0 \cdot 005)$. Filled symbols represent $C 3 b$, open
symbols TCC. Ileum, $\bigcirc$; caecum and ascending colon, $\Delta \triangle$; transverse colon, $\diamond ;$ descending and sigmoid colon, $\square \square$; rectum, $\nabla \nabla$. 

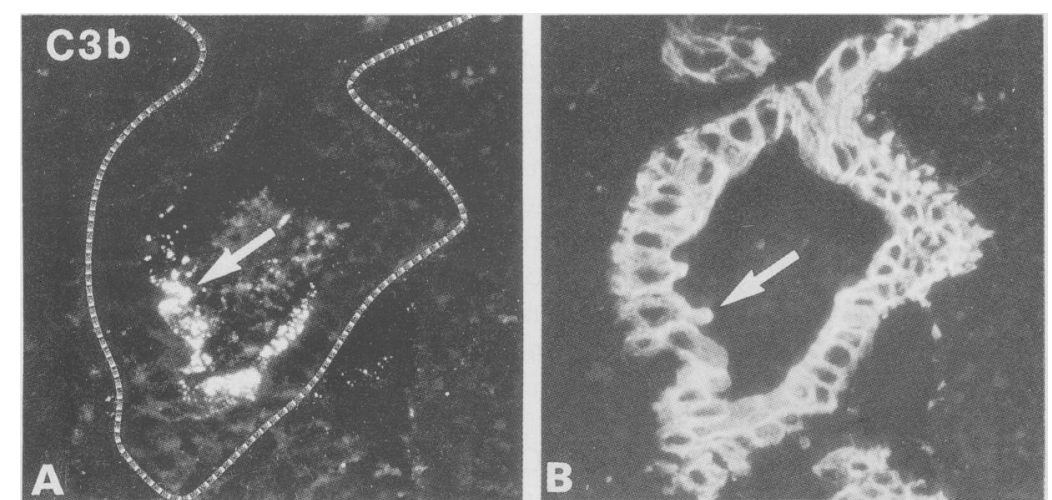

Figure 3: Two colour immunofluorescence staining for $C 3 b(A)$ and keratin $(B)$ on directly ethanol fixed colonic mucosa from a patient with Crohn's disease of the colon. $C 3 b$ positive globular elements (arrow) were attached to and partly located within the epithelium.

terminal complement complex positivity was more diffuse (not shown). Similar C3b positive elements were observed attached to and/or located within the epithelium in nine patients. Aggregates of $\mathrm{C} 3 \mathrm{~b}$ positive globular elements were observed in the lamina propria in directly ethanol fixed specimens from six patients (Fig 4). These aggregates were apparently located within lymphatic vessels as visualised also with avidin biotin complex peroxidase (Fig 4C) and alkaline phosphatase antialkaline phosphatase staining technique in three patients examined.

No epithelial deposition of IgG, Clq, or C4c was observed in prewashed tissue samples from Crohn's disease (Fig 5).

\section{Ulcerative colitis}

All selected ulcerative colitis samples showed deposition of $\mathrm{IgGl}, \mathrm{C} 3 \mathrm{~b}$ and terminal complement complex on the luminal face of individual enterocytes, only interrupted by goblet cells as previously reported. " Crypt abscesses and luminal contents often stained for terminal complement complex but only weak and scattered C3b positivity was observed, contrasting the intense mucus-associated staining for $\mathrm{C} 3 \mathrm{~b}$ in Crohn's disease.

Epithelium related staining for $\mathrm{C} 4 \mathrm{c}$ was observed in three of the five patients but it was less prominent than seen for C3c. Supraepithelial Clq was weak and observed only occasionally. Three colour staining for IgG1, C3b and C4c or $\mathrm{Clq}$ revealed that the $\mathrm{IgGl}$ and $\mathrm{C} 3 \mathrm{~b}$ positive epithelial deposits often costained for $\mathrm{C} 4 \mathrm{c}$ (though weaker than for $\mathrm{C} 3 \mathrm{~b} / \mathrm{C} 3 \mathrm{c}$ ). Such deposits were observed in all three samples (Fig 6). C3b/ terminal complement complex positive deposits in the absence of both $\mathrm{IgGl}$ and $\mathrm{C} 4 \mathrm{c} / \mathrm{Clq}$ were also observed. The other two samples contained either epithelial $\mathrm{C} 3 \mathrm{~b}$ and terminal complement complex deposits in the absence of IgGl and Clq/ $\mathrm{C} 4 \mathrm{c}$, or only IgG1 in the absence of complement components.

C3b positive globular elements were often observed in the lumen and were attached to the surface epithelium in one of the ulcerative colitis samples.

\section{VASCULAR COMPLEMENT}

Submucosal blood vessels in both ileum and

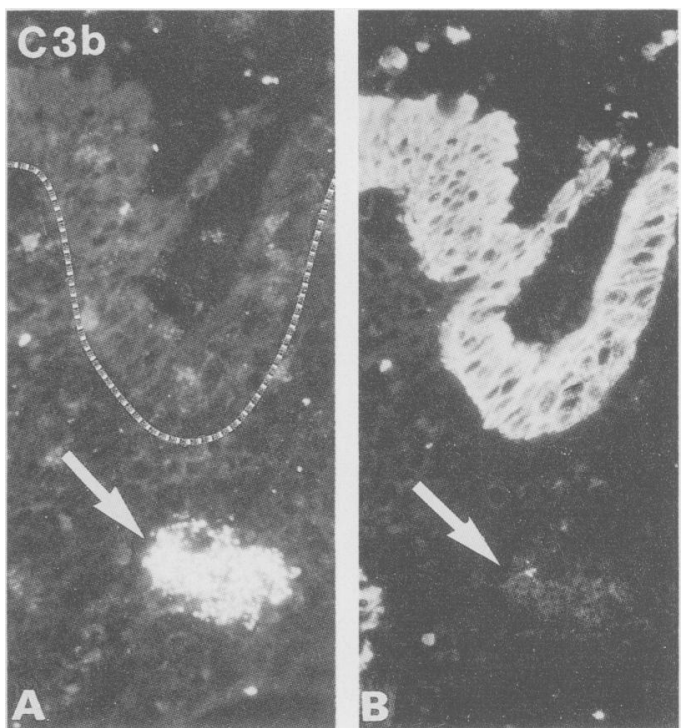

B

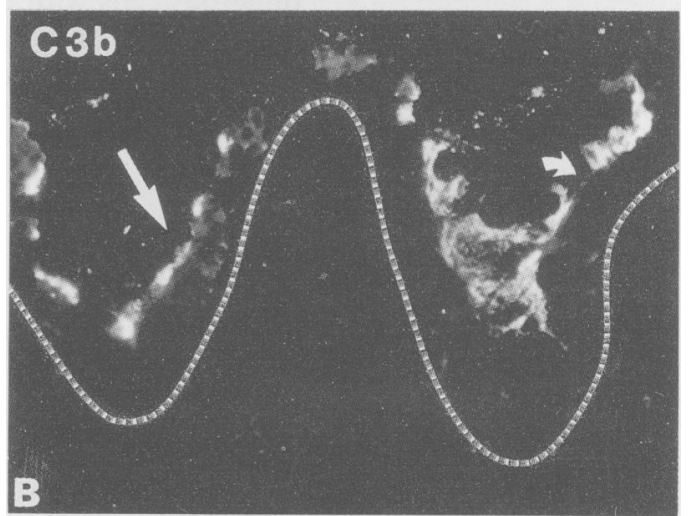

Figure 5: Two colour immunofluorescence staining for (A) IgGl and (B)C3b in prewashed colonic mucosa from a patient with Crohn's colitis. No IgGI (or any other IgG subclass) was observed within the $C 3 b$-positive epithelial deposits (large arrow). Epithelial cell (small arrows) with diffuse staining for IgGI in the cytoplasm had taken up this serum protein in vivo, perhaps because of complement induced leakage. 

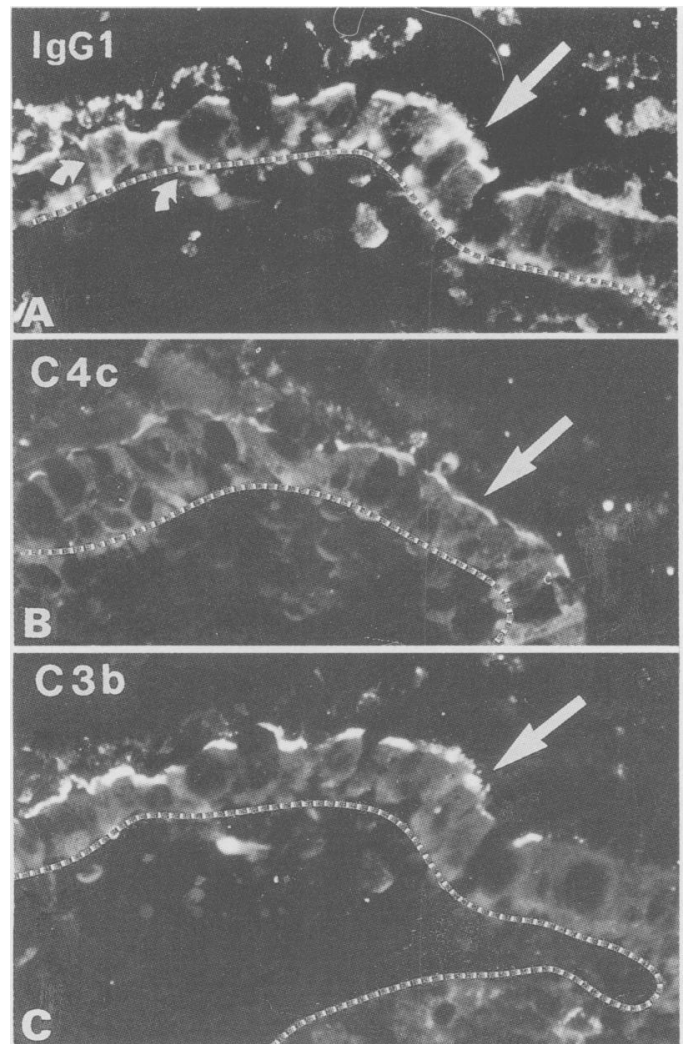

Figure 6: Immunofluorescence staining for $(A) \operatorname{Ig} G 1,(B)$ $C 4 c$ and $(C) C 3 b$ on two serial sections of colonic mucosa from a patient with ulcerative colitis ( $a$ and $b$, paired staining). In this disorder, the epithelial C3b deposits (c) often costained for both IgGI (a) and the classical activation pathway component $C 4 c(b)$. Epithelial detachment had presumably been induced in vivo as the epithelium stained diffusely for serum proteins such as IgGI (arched arrow). Note segmental costaining apically on the epithelial surface (arrows).

colon were intensely positive for terminal complement complex, and to a lesser extent for $\mathrm{C} 3 \mathrm{~b}$, as previously reported. ${ }^{2021}$ Some of the $\mathrm{C} 3 \mathrm{~b}$ positive submucosal blood vessels in both Crohn's disease and ulcerative colitis showed a segmental costaining for $\mathrm{Clq}$ and $\mathrm{C} 4 \mathrm{c}$. Two colonic samples from Crohn's disease contained a submucosal blood vessel that stained for all complement components $(\mathrm{Clq}, \mathrm{C} 3 \mathrm{~b}, \mathrm{C} 4 \mathrm{c}$ and terminal complement complex) in addition to some weak IgGl positivity (not shown). Numerous cells with cytoplasmatic staining for $\mathrm{C} 3 \mathrm{c}, \mathrm{C} 4 \mathrm{c}, \mathrm{Clq}$ and occasionally also IgGl were observed deep in the lamina propria and between the smooth muscular cells in inflamed sections (not shown).

\section{CONTROLS}

Epithelial complement deposition was not observed in six non-inflamed ileal samples from six controls and not in $\mathbf{4 2}$ of $\mathbf{4 4}$ colonic samples from 26 control patients. ${ }^{11}$

\section{Discussion}

Our previous observation of epithelium related IgGl and activated complement (C3b and terminal complement complex) in active ulcerative colitis reflected a potentially destructive immune reaction caused by autoantibodies to epithelial brush border associated protein(s). " Here we report that luminal complement activation also occurs in Crohn's disease of the ileum and colon. Lack of IgG and classically complement activation components (Clq and $\mathrm{C} 4 \mathrm{c}$ ) within the epithelial $\mathrm{C} 3 \mathrm{~b} /$ terminal complement complex deposits, however, suggests that initiators of the alternative pathway are more important in Crohn's disease than in ulcerative colitis. In the latter disorder epithelial immune deposits often costain for IgG1 and $\mathrm{C} 4 \mathrm{c}$ and also occasionally for $\mathrm{Clq}$, strongly suggesting that IgGl induces classical pathway activation. Epithelial immune deposits negative for IgG1, Clq and C4c are also observed, however, probably reflecting that alternative pathway activation also occurs in ulcerative colitis.

The two complement activation pathways are not strictly separate because antibodies and immune complexes may also activate the alternative pathway, ${ }^{22}$ and agents such as cardiolipin, ${ }^{23}$ C-reactive protein ${ }^{24}$ and bacterial (Escherichia coli) surface antigens ${ }^{26}$ may initiate the classical pathway. In addition, $\mathrm{C} 3 \mathrm{~b}$ produced by classical activation may complex with factor $\mathrm{B}$ to generate the alternative pathway $\mathrm{C} 3$ convertase $(\mathrm{C} 3 \mathrm{bBb})$, resulting in increased $\mathrm{C} 3$ activation (alternative pathway amplification). It is therefore difficult to determine the main activation pathway on the basis of immunohistochemical staining for complement components in immune deposits. Nevertheless, codeposition of IgGl in ulcerative colitis but not in Crohn's disease, strongly suggests that autoantibodies to the colonic epithelium are involved in the epithelial complement deposition only in the former disease. Also, patients with Crohn's disease have been found to have higher serum levels of the alternative pathway activation product $\mathrm{Bb}$ than patients with ulcerative colitis.

The subepithelial deposition of C3d, terminal complement complex and S-protein (presumably representing the soluble form of terminal complement complex, SC5b-9) observed in affected ileum and colon might have represented fluid face complement activation secondary to epithelial destruction. Alternatively, soluble immune complexes generated in the basement membrane zone could have induced subepithelial compliment activation and induced epithelial damage. These deposits, however, were mainly seen beneath intact epithelium in Crohn's disease, contrasting with ulcerative colitis where such deposits primarily were observed beneath or close to damaged epithelium.

Ahrenstedt $e t a l^{27}$ recently reported that patients with Crohn's disease of the ileum have increased concentrations of C3 in jejunal lavage fluid. It was suggested that this finding reflected activated $\mathrm{C} 3$ because most was of a molecular size similar to the complement split product C3c. This does not seem to be a general small intestinal phenomenon, however, because $\mathrm{C} 3 \mathrm{~b} / \mathrm{C} 3 \mathrm{c}$ positivity ( $\mathrm{mAb}$ bH6) was observed only in mucus of affected ileum.

The epithelial complement deposition in Crohn's colitis tended to be more granular than in ulcerative colitis. The globular elements positive for $\operatorname{IgG} 1, \operatorname{IgG} 2, \operatorname{IgG} 3$, and $\mathrm{C} 3 \mathrm{~b}$ observed in the mucus, and the $\mathrm{C} 3 \mathrm{~b}$ positive elements on the epithelium and in the lamina propria, resembled surface staining of microorganisms. This sug- 
gested an immune attack but the putative microorganisms might have bound $\mathrm{C} 3 \mathrm{~b}$ by complement receptor like structures as recently shown for Candida albicans. ${ }^{28}$ Such $\mathrm{C} 3 \mathrm{~b}$ coating does not afford opsonisation and the microorganisms may escape phagocytosis. In an electron microscopic study of Crohn's disease, Thyberg $e a^{29}$ observed partly degraded bacteria in lamina propria macrophages and epithelial cells regardless of the severity of the lesion; and Aluwihare ${ }^{30}$ found intramural bacteria in six of 11 colonic specimens with intact epithelium and minimal inflammatory changes. Patients with Crohn's disease have, in addition, higher serum concentrations of agglutinating antibodies to anaerobic coccoid roods (Eubacterium contortum, Coprococcus comes, Peptostreptococcus productus) than patients with ulcerative colitis. ${ }^{31}$ Furthermore, only Crohn affected mucosa contains 160 $\mathrm{kDa}, 120-\mathrm{kDa}$, and $110-\mathrm{kDa}$ proteins that are exclusively precipitated by sera from patients, ${ }^{32}$ suggesting an immune response to foreign antigens selectively located in the Crohn lesion.

Taken together, these results support the suggestion that Crohn's disease may be caused by immune responses to relatively non-pathogenic replicating microorganism(s). The actual lesion may be produced by an activated immune system rather than directly by the microorganism. Many microbial candidates have been suggested, including Mycobacteria, Spheroblasts, and wall deficient Salmonella species, but their pathogenetic significance remains obscure. ${ }^{33-39}$ This is also true for the $\mathrm{C} 3 \mathrm{~b}$ coated elements seen on the epithelium in our study, the same observation was made in some ulcerative colitis specimens. Conversely, the aggregates of $\mathrm{C} 3 \mathrm{~b}$ coated globular elements in the lamina propria have not been observed in ulcerative colitis despite severe epithelial damage. Their nature therefore needs further elucidation.

We have previously reported that patients with Crohn's disease and ulcerative colitis have increased deposition of terminal complement complex ${ }^{20}$ and $\mathrm{C}^{2} \mathrm{~b}^{21}$ in submucosal blood vessels, suggesting that vascular complement activation takes part in the pathogenesis. The vascular immune deposits do not generally contain detectable Ig components. ${ }^{40}$ In this limited study of prewashed tissue specimens, however, we observed that the vascular $\mathrm{C} 3 \mathrm{~b}$ deposits occasionally costained for $\mathrm{Clq}$ and $\mathrm{C} 4 \mathrm{c}$, suggesting classical complement activation. Furthermore, by three colour immunofluorescence staining, making it possible to focus on the relatively few terminal complement complex positive vessels containing both $\mathrm{C} 3 \mathrm{~b}$ and $\mathrm{C} 4 \mathrm{c}$, we observed some weak segmental IgGl positively in submucosal vessels of two colonic specimens from Crohn's disease. The nature of this observation needs further examination, but vascular complement activation may be involved in the multiple intestinal infarction that seems to be a feature of Crohn' disease. ${ }^{+1}$

Although activated $\mathrm{T}$ cells have been suggested to be particularly important in the pathogenesis of Crohn's disease, ${ }^{42}$ local complement activation may contribute to the immunopathology. The absence of $\mathrm{IgG}, \mathrm{Clq}$, and $\mathrm{C} 4 \mathrm{c}$ within the epithelium related immune deposits suggests that other immunopathological mechanisms operate in Crohn's disease than in ulcerative colitis.

TSH is a research fellow of the Norwegian Cancer Society.

1 Elson CO. The immunology of inflammatory bowel disease In: Kirsner JB, Shorter RG, eds. Inflammatory bowel disease. Philadelphia: Lea \& Febiger, 1988: 97-164.

2 Baklien K, Brandtzaeg P. Comparative mapping of the loca distribution of immunoglobulin-containing cells in ulcerative colitis and Crohn's disease of the colon. Clin Exp Immunol 1975; 22: 197-209.

3 Kett K, Rognum TO, Brandtzaeg P. Mucosal subclass distribution of IgG-producing cells is different in ulcerative colitis and Crohn's disease of the colon. Gastroenterology 1987; 93: 919-24.

4 Scott MG, Nahm MH, Macke K, Nash GS, Bertovich MJ, MacDermott RP. Spontaneous secretion of IgG subclasse by intestinal mononuclear cells: differences between ulcerative colitis, Crohn's disease, and controls. Clin Exp Immuno 1986; 66: 209-15.

5 Simson T, Elmgren J. Defective modulation of complement in Crohn's disease. Scand f Gastroenteral 1985; 20: 883-6.

6 Elmgreen J, Berkowicz A, Sorensen H. Hypercatabolism of complement in Crohn's disease - assessment of circulatin C3c. Acta Med Scand 1983; 214: 403-7.

7 Hodgson HJF, Potter BJ, Jewell DP. C3 metabolism in ulcerative colitis and Crohn's disease. Clin Exp Med 1977; 28: $490-5$.

8 Teisberg P, Gjone E. Humoral immune system activity in inflammatory bowel disease. Scand $\mathcal{F}$ Gastroenterol 1975; 10: $545-9$.

9 Hodgson HJF, Potter BJ, Jewell DP. Humoral immune system in inflammatory bowel disease: I. Complement system in inflammatory bow

10 Lake AM, Stitzel AE, Urmson JR, Walker WA, Spitzer RE Complement alterations in inflammatory bowel disease. Gastroenterology 1979; 76: 1374-9.

11 Halstensen TS, Mollnes TE, Garred P, Fausa O, Brandtzae $P$. Epithelial deposition of immunoglobulin $\mathrm{Gl}$ and activated complement (C3b and terminal complement complex) in ulcerative colitis. Gastroenterology 1990; 98: 1264-71.

12 Brandtzaeg P. Mucosal and glandular distribution of immunoglobulin components. Immunohistochemistry with a cold ethanol-fixation technique. Immunology 1974;26; 1101-14.

13 Mollnes TE, Lea T, Harboe M, Tschopp J. Monoclona antibodies recognizing a neoantigen of poly(C9) detect the human terminal complement complex in tissue and plasma. Scand I Immunol 1985; 22: 183-95.

14 Dahlbäck K, Lofberg H, Dahlbäck B. Localization of vitronectin (S-protein of complement) in normal human skin. Acta Dermatol Venereol 1986; 66: 461-7.

15 Garred P, Mollnes TE, Lea T, Fisher E. Characterization of monoclonal antibody MoAb bH6 reacting with a neoepitop of human $\mathrm{C} 3$ expressed on $\mathrm{C} 3 \mathrm{~b}, \mathrm{iC} 3 \mathrm{~b}$, and $\mathrm{C} 3 \mathrm{c}$. Scand f Immunol 1988; 27 : 311-9.

16 Huitfeldt HS, Brandtzaeg P. Various keratin antibodies produce immunohistochemical staining of human myocardium and myometrium. Histochemistry 1985; 83: 381-9.

17 Jefferis R, Reimer CB, Skavril F, de Lange G, Ling NR, Lowe $\mathrm{J}$, et al. Evaluation of monoclonal antibodies having specificity for human IgG sub-classes: results of an IUIS/WHO ficity for human IgG sub-classes: results of an IUIS/

18 Brandtzaeg P, Rognum TO. Evaluation of tissue preparation methods and paired immunofluorescence staining for immunocytochemistry of lymphomas. Histochem $\mathcal{F} 1983 ; 15$. $655-89$

19 Mason G. Immunocytochemical labelling of monoclonal antibodies by the APAAP immunoalkaline phosphate tech nique. In: Bullock GR, Petrusz P, eds. Immunocytochemistry 1985; 3: $25-43$.

20 Halstensen TS, Mollnes TE, Fausa O, Brandtzaeg P. Deposits of terminal complement complex (TCC) in muscularis mucosae and submucosal vessels in ulcerative colitis and Crohn's disease of the colon. Gut 1989; 30: 361-6.

21 Halstensen TS, Mollnes TE, Brandtzaeg P. Persistent complement activation in submucosal blood vessels of active inflammatory bowel disease: Immunohistochemical inflammatory bowel disease: Immund

22 Ratnoff WD, Fearon DT, Austen KF. The role of antibody in the activation of the alternative complement pathway. Springer Semin Immunopathol 1983; 6: 361-71.

23 Vacsovics T, Tschopp J, Kress A, Isliker H. Antibodyindependent activation of $\mathrm{Cl}$, the first component of complement, by cardiolipin. F Immunol 1985; 135: 2695-700.

24 Volanakis JE, Kaplan MH. Interaction of C-reactive protein complexes with the complement system. F Immunol 1974; 113: 9-17.

25 Claus DR, Siegel J, Petras K, Osmand AP, Gewurz H. Interaction of $\mathrm{C}$-reacting protein with the first component of human complement. F Immunol 1977; 119: 187-92.

26 Aubert B, Chesne S, Arlaud GJ, Colomc MG. Antibodyindependent interaction between the first component of independent interaction between the futer membrane of Escherichia coli. Biochem f 1985; 232: 513-9.

27 Ahrenstedt Ö, Knutson L, Nilsson-Ekdahl K, Odlin B, Hällgren $R$. Enhanced local production of complement components in the small intestine of patients with Crohn's components in the small intestine of patient

28 Hostetter MK, Lorenz JS, Preus L. Kendrick KE. The iC3b 
receptor on Candida albicans: subcellular localization and modulation of receptor expression by glucose. $\mathcal{F}$ Infect $D$ is 1990; 16: 761-8.

29 Thyberg J, Graf W, Klingenstrom P. Intestinal fine structure in Crohn's disease. Lysosomal inclusions in epithelial cells and macrophages. Virchows Arch 1981; 391: 141-52.

30 Aluwihare APR. Electron microscopy in Crohn's disease. Gut $1971 ; 12: 509-18$

31 Auer IO, Wensinck RF, van de Merwe JP, Schmidt H. Selected bacterial antibodies in Crohn's disease and ulcerative colitis. Scand F Gastroenterol 1983; 18: 217-23.

32 Bagchi S, Das KM. Detection and partial characterization of Crohn's disease tissue specific proteins recognized by Crohn's disease sera. Clin Exp Immunol 1984; 55: 41-8.

33 van der Merwe JP. The human faecal flora and Crohn's disease. Antonie Van Leeuwenhoek 1984; 50: 691-700.

34 Chiodini RJ, van Kruiningen HJ, Thayer WR, Merkal RS, Coutu JA. Possible role of mycobacteria in inflammatory bowel disease. I. An unclassified mycobacterium specie isolated from patients with Crohn's disease. Dig Dis Sci

35 Chiodini RJ, van Kruiningen HJ, Thayer WR, Coutu JA. Spheroplastic phase of mycobacteria isolated from patients with Crohn's disease. $\mathcal{F}$ Clin Microbiol 1986; 24: 357-63.
36 Graham DY, Marakesich DC, Yoshimura HH. Mycobacteria and inflammatory bowel disease result of culture. Gastroenterology 1987; 92: 436-42.

37 Butcher PD, McFadden JJ, Hermon-Taylor J. Investigation of mycobacteria in Crohn's disease tissue by southern blotting and DNA hybridization with cloned mycobacterial genomic DNA probes from a Crohn's disease isolated mycobacteria. Gut 1988; 29: 1222-8.

38 Markesich DC, Graham DY, Yoshimura HH. Progress in culture and subculture of spheroplast and fastidious acid-fast bacilli isolated from intestinal tissues. 7 Clin Microbiol 1988; 26: $1600-3$

39 Kobayashi K, Blaser MJ, Brown WR. Immunohistochemical examination for mycobacteria in intestinal tissues from patients with Crohn's disease. Gastroenterology 1989; 96: patients $1009-15$.

40 Halstensen TS. Complement deposits in inflammatory bowel disease. Gastroenterology 1990; 99: 1541-2.

41 Wakefield AJ, Sawyerr AM, Dhillon AP, Pittilo RM, Rowles PM, Lewis AAM, et al. Pathogenesis of Crohn's disease: PM, Lewis AAM, et al. Pathogenesis of Crohn's disease:
multifocal gastrointestinal infarction. Lancet 1989; ii: 105762 .

42 James SP. Cellular immune mechanisms in the pathogenesis of Crohn's disease. In vivo 1988; 2: 1-8. 
tumour a liverown proliferative process or a more generalised disease. ...' (p 101) are difficult to negotiate!

N W GARVIE

Gastroenterology. Clinician's guide to nuclear medicine. By L K Harding and P J Robinson. (Pp 148; illustrated; £12.50.) London: Churchill Livingstone, 1991.

Many patients whose complaints refer to the gastrointestinal tract have disorders of function. It is, therefore, surprising that the techniques of nuclear medicine are underused in this specialty. The main role of radionuclide techniques is in the non-invasive demonstration of pathophysiological disorders. The motility and synchronisation of oesophageal contraction is given by a few swallows of ${ }^{9 \mathrm{~m}} \mathrm{Tc}$ labelled fruit juice. Gastrooesophageal reflux and gastric emptying, small bowel transit and colonic motility in constipation, irritable bowel syndrome, and diarrhoea are able to be assessed non-invasively. There is the demonstration of the site of gastrointestinal bleeding before angiography, and the use of radioactive $B_{12}$ and SeHCAT $\left({ }^{75} \mathrm{Se}\right.$ homotaurocholate) and ${ }^{14} \mathrm{C}$ breath tests in defining the nature of malabsorption.

The evaluation of inflammatory bowel disease and the demonstration of abscess with radiolabelled white cells are discussed. Liver blood flow, biliary kinetics, gallbladder function, and hyposplenia are considered. The distinction between recurrence of colorectal cancer and postsurgical fibrosis is made with radiolabelled monoclonal antibodies. All these subjects and more are covered clearly, concisely, and with a clinical emphasis in this genuine pocket book. It is essential reading for gastroenterologists both in training and retraining. It is strongly recommended.

K E BRITTON

All titles reviewed here are available from the BMJ Bookshop, PO Box 295, London WCIH 9TE. Prices include postage in the UK and for members of the British Forces Overseas, but overseas customers should add $15 \%$ to the value of the order for postage and packing. Payment can be made by cheque in sterling drawn on a UK bank, or by credit card (Mastercard, Visa, or American Express), stating card number, expiry date, and full name.

\section{BOOKS RECEIVED}

alk symposium 59. Mechanisms of peptic ulcer healing. Edited by F Halter, A Garner, G N J Tytgat (Pp 318; illustrated; £65.00.) Dordrecht: Kluwer Academic, 1991.

Falk symposium 60. Inflammatory bowel disease. Edited by $\mathrm{H}$ Goebell, $\mathrm{K}$ Ewe, H Malchow. (Pp 493; illustrated; £80.00.) Dordrecht: Kluwer Academic, 1991.

Advances in nutrition and top sport. Edited by $\mathrm{F}$ Brouns. ( $\mathrm{Pp} 222$; illustrated; $£ 97.00$.) Basel: S Karger, 1991.

Acute liver failure. Proceedings of the 11th BSG/SK \& F International Workshop 1990. Edited by Roger Williams and Robin D Hughes. (Pp 114; illustrated; no charge.) Welwyn: Smithkline Beecham Pharmaceuticals, 1991.

Immunologic research. Basic mechanisms in mucosal immunology. Proceedings of the International Meeting. Edited by M Zeitz, S P James, W Strober, E-O Rieken. (Pp 370; illustrated; £36.20.) Basel: S Karger, 1991.

Textbook of internal medicine. Edited by $W$ E Kelly. (Pp 1600; illustrated; \$66.00.) Philadelphia: J B Lippincott, 1991.

Viral hepatitis and liver disease. Edited by $\mathrm{F}$

Blaine Hollinger, Stanley M Lemon, Harold S Margolis. (Pp 800; illustrated; £96.00.) Baltimore: Williams and Wilkins, 1991.

Gut-derived infectious toxic shock. Edited by H Cottier, R Kraft. (Pp 370; illustrated; $£ 150.00$.) Basel: S Karger, 1992.

Pancreatitis. H Sarles, C D Johnson, J F Sauniere. (Pp 249; illustrated; price not stated.) Paris: Arnette Blackwell, 1991.

Advances in gastroenterology. No 3. Nonulcer dyspepsia. F Di Mario, G Mastrapasqua, D Madia, L Aggio, G Mastropaolo. (Pp 130; illustrated £17.00.) Padova: Piccin Nuova Libraria, 1991.

Staging and treatment of gastric cancer. Edited by C Cordiano, G de Manzoni. (Pp 324; illustrated; £35.00.) Padova: Piccin Nuova Libraria, 1991.

Watching in the dark. Artemis Cooper. ( $\mathrm{Pp}$ 134; not illustrated; £9.50.) London, John Murray, 1992.

Clinical application of radioimmunoassay. Ferenc A Laszlo, Tama Janaky. (Pp 230; illustrated; \$32.00.) Budapest: Akademiai Kiado, 1992.

The dictionary of modern medicine. J C Segen. (Pp 800; illustrated; £48.00.) Carnforth, UK: Parthenon Publishing, 1992.

Advances in gastroenterology. Chronic atrophic gastritis. Pathophysiological and clinical features. F Di Mario, F Farinati, G Leandro. (Pp 132; illustrated; £17.00.) Padova: Piccin Nuova Libraria, 1991.

\section{NOTE}

\section{Sir Francis Avery Jones BSG Research} Award 1993

Applications are invited by the Education Committee of the British Society of Gastroenterology who will recommend to Council the recipient of the 1993 Award. Applications (15 copies) should include:

(1) A manuscript (2 A4 pages only) describing the work conducted.

(2) A bibliography of relevant personal publications.

(3) An outline of the proposed content of the lecture, including title.

(4) A written statement confirming that all or a substantial part of the work has been personally conducted in the United Kingdom or Eire.

The award consists of a medal and a $£ 100$ prize. Entrants must be 40 years or less on 31 December 1993 but need not be a member of the BSG. The recipient will be required to deliver a 40 minute lecture at the Spring Meeting of the Society in 1993. Applications (15 copies) should be made to: The Honorary Secretary, BSG, 3 St Andrew's Place, London NW1 4LB by 1 December 1992.

\section{Correction}

Surface epithelium related activation of complement differs in Crohn's disease and ulcerative colitis by Halstensen $e t$ al, July 1992; 33: 902-8. We regret that an error occurred in this paper. The sentence on page 902 should read 'The results showed deposition of both $\mathrm{C} 3 \mathrm{~b}$ and terminal complement complex at the luminal surface. No IgG was colocalised in these deposits, however, in contrast with our previous observations in ulcerative colitis."' 